\title{
Bone marrow mesenchymal stem cells modified pathological changes and immunological responses in ovalbumin-induced asthmatic rats possibly by the modulation of miRNA155 and miRNA133
}

\author{
Mahdi Ahmadi ${ }^{1,2}$, Reza Rahbarghazi ${ }^{3,4}$, Amir-Ali Shahbazfar ${ }^{5}$, Horeyeh Baghban $^{1}$ and Rana \\ Keyhanmanesh ${ }^{6,7}$ \\ ${ }^{1}$ Department of Physiology, Faculty of Medicine, Tabriz University of Medical Sciences, Tabriz, Iran \\ 2 Student Research Committee, Tabriz University of Medical Sciences, Tabriz, Iran \\ ${ }^{3}$ Stem Cell Research Center, Tabriz University of Medical Sciences, Tabriz, Iran \\ ${ }^{4}$ Department of Applied Cell Sciences, Faculty of Advanced Medical Sciences, Tabriz University of Medical Sciences, Tabriz, Iran \\ ${ }^{5}$ Department of Pathology, Faculty of Veterinary Medicine, University of Tabriz, Tabriz, Iran \\ ${ }^{6}$ Drug Applied Research Center, Tabriz University of Medical Sciences, Tabriz, Iran \\ ${ }^{7}$ Emergency medicine research team, Tabriz University of Medical Sciences, Tabriz, Iran
}

\begin{abstract}
In the current experiment, we investigated the immune-modulatory potential of mesenchymal stem cells (MSCs) and conditioned media (CM) in attenuating of chronic asthmatic changes in a rat model. Male rats were divided into control (C) and ovalbumin-sensitized (S) groups, which further allocated into three subgroups; rats received systemically $50 \mu$ volume of PBS (C and S groups), $\mathrm{CM}$ (CSV and SSV groups) and rats received intravenous infusion of $2 \times 10^{6}$ bone marrow-derived mesenchymal stem cells (rBMMSCs) (CCV and SCV groups). Two weeks later, the expression of interleukin (IL)-4, IL-13, and IL-10, miRNA133, and miRNA155 was measured by real-time PCR. Pathological changes and the recruitment of rBMMSCs into pulmonary parenchyma were evaluated by histopathological and immunofluorescence analyses, respectively. The systemic injection of rBMMSCs, but not CM, decreased the levels of IL-4, IL-13, IL-10, miRNA133, miRNA155 and reduced pathological changes in sensitized rats as compared with other sensitized groups $(p<0.001$ to $p<0.05)$. rBMMSCs transmigrated to lung tissue in cell-administrated rats, albeit intensity of asthmatic changes, in turn, affected the amount of recruited cells. Collectively, our data suggest the potential role of MSCs, but not CM, in reducing pathological changes possibly via the modulation of miRNA133 and miRNA155 during asthmatic changes.
\end{abstract}

Key words: Asthma - Conditioned media - Mesenchymal stem cells - miRNA133 - miRNA155

\section{Introduction}

Asthma is commonly regarded as a debilitating chronic respiratory disorder caused by a plethora of factors with profound impacts on socioeconomic costs. Based on statistics, asthma involves approximately 300 million people of all ages worldwide (Murray and Lopez 1997; D’Cruz et al. 1999;

Correspondence to: Rana Keyhanmanesh, Drug Applied Research Center, Tabriz University of Medical Sciences, Tabriz, Iran

E-mail: rkeyhanmanesh@gmail.com

keyhanmaneshr@tbzmed.ac.ir
Bharadwaj and Agrawal 2004; Martinez 2007). Despite substantial advances in human medicine, asthma is not curable permanently. The current conventional pharmacotherapy approaches only suppress and alleviate asthma-related attacks and have different side effects. The asthma manifestations are most likely to be returned following treatment discontinuation (Guilbert et al. 2006; Douglas et al. 2008; Keyhanmanesh et al. 2014).

Histopathological changes in the lung tissues of asthmatic subjects are mainly induced by the chronic inflammatory responses due to the up-regulation of cytokines produced by type $2 \mathrm{~T}$ helper cells (Th2) (Huang et al. 2001). Therefore, 
emerging therapeutic strategies for asthma management should be focused on the reversal of Th2/Th1 imbalance and the control of inflammation rate (Gholamnezhad et al. 2014; Aslani et al. 2016; Fallahi et al. 2016). Th2-derived cytokines such as interleukin IL-4 and IL-13 orchestrated asthma pathophysiology by the interaction with lungresident fibroblasts, epithelial cells and smooth muscle cells (Gholamnezhad et al. 2014; Fallahi et al. 2016). On the other hand, IL-10, an anti-inflammatory cytokine is secreted by $\mathrm{T}$ regulatory cells could down-regulate Th2-mediated inflammatory response in allergic asthma. Hence, the modulation of pro- and anti-inflammatory cytokines is thought to be essential for a successful resolution of inflammation in asthma (Todorova 2007). In line with this statement, the immune-modulatory characteristics of mesenchymal stem cells (MSCs), are orchestrated by trans-differentiation capacity and paracrine activity, makes them very powerful therapeutic tools for a wide spectrum of inflammatory diseases such as asthma (Kyurkchiev et al. 2014; Ma et al. 2014). The survival and differentiation of the MSCs at the injured sites are confined possibly because of ischemic microenvironment. Therefore, it is proposed that MSCs paracrine effect is essential to exert therapeutic effects (Gallina et al. 2015). Since stem cell-secretome yields some of the therapeutic effects, it is logical that the paracrine effects of MSCs could be observed in their condition media (CM) (Horie et al. 2012; Gallina et al. 2015). The administration of CM could circumvent some of the current problems associated with MSCs such as immunological reactions, tumorigenicity, infectious agents, total costs, and long waiting time for cellular expansion (Sze et al. 2007). A great body of studies unveiled BMMSCs suppressed Th2 cell responses and mitigated inflammation in ovalbumin-induced asthmatic mice (Goodwin et al. 2011; Sun et al. 2012). However, underlying mechanisms driven by MSCs during asthma have still not been fully documented and must be addressed in animal models that are applicable to human, especially rat.

MicroRNAs (miRNAs) are conceived as a novel class of biomarkers for numerous inflammatory diseases (Mi et al. 2013). They possess a single-stranded, small, non-coding RNAs, suppressing gene expression at the post-transcriptional level by the subversion or inhibition of target mRNAs. miRNAs were found to participate in airway inflammatory regulation via the modulation of Th2 cell function (Kishore et al. 2014; Rebane and Akdis 2014; Simpson et al. 2014).

The global pattern of miRNA profiles in respiratory niche can be regulated by inflammatory agents (Wang et al. 2011). Commensurate with this statement, a plethora of experiments showed multiple miRNAs expressed differentially in murine lung tissues following sensitization with ovalbumin (Garbacki et al. 2011). For instance, in an animal model of asthma, the up-regulation of miRNA155 was recorded while miRNA133 was down-regulated as compared with the control group (Kai et al. 2015). Actually, the manipulation of these miRNAs in numerous allergic asthmatic models attenuated the inflammatory status and closed it to nearnormal ranges (Wang et al. 2011; Kai et al. 2015).

However, no enough data exist on the modulatory effects of MSCs related to the expression of miRNAs in asthmatic rats. The elucidation of the underlying mechanisms governed by MSCs in asthma will help to achieve the beneficial clinical application for stem cell therapy in human medicine. Therefore, we here hypothesized that MSC-mediated immunemodulatory properties would be directed via the regulation of miRNA expression in asthmatic lung tissues.

\section{Materials and Methods}

\section{Ethical issues}

All phases of our study were implemented in a guideline with of "The Care and Use of Laboratory Animals published by the National Institutes of Health" (NIH Publication No. 8523, revised 1996) and agreed by the local ethical committee of Tabriz University of Medical Sciences (No: TBZMED. REC.1394.386).

\section{Cell isolation and expansion procedure}

Rat bone marrow-derived mesenchymal stem cells (rBMMSCs) were extracted in accordance with previously published protocols (Rahbarghazi et al. 2012). In brief, the animals were killed humanely by an overdose combination of xylazine and ketamine solution. After complete dissection and the removal of femurs and cutting the epiphysis with a scissor, the medullary components were aspirated under aseptic conditions immediately by phosphate-buffered solution (PBS) containing 2\% fetal bovine serum (FBS; Gibco, USA). Then, fresh bone marrow-derived mononuclear cells were harvested by gradient centrifugation using Ficoll solution (Sigma, USA) at 400 $\times g$ for $20 \mathrm{~min}$ and washed next twice by PBS. Thereafter, isolated cells were resuspended in Dulbecco's modified Eagle's medium-low glucose (DMEM/LG; Gibco, USA) supplemented with $20 \% \mathrm{FBS}, 100 \mathrm{U} / \mathrm{ml}$ penicillin and $100 \mathrm{mg} / \mathrm{ml}$ streptomycin (Biosera, UK). Finally, $1 \times 10^{5}$ cells were seeded in 6-well culture plates (SPL). The medium was replenished every 3-4 days. For cell subculture, rBMMSCs were trypsinized at 70-80\% confluency and subjected to subsequent analyses, at passage three.

\section{Immunophenotypic characterization of isolated rBMMSCs}

rBMMSCs were immunophenotyped by flow cytometry analysis (Rahbarghazi et al. 2014). We used a panel of dif- 
ferent monoclonal antibodies directed against the stem cell surface markers, including FITC-conjugated anti-CD133, CD44, and CD34 as well as PE-conjugated anti-CD31 (all purchased from ebioscience, USA). Isotype control antibodies were also used to normalize background staining. Cells were trypsinized by using $0.25 \%$ Trypsin-EDTA solution (Gibco, USA), washed by PBS, and blocked by $1 \%$ bovine serum albumin (BSA; Sigma, USA) for $15 \mathrm{~min}$. Antibodies were added into $100 \mu \mathrm{l}$ of PBS containing $5 \times 10^{5}$ cells and incubated for the next $30 \mathrm{~min}$ at RT according to manufacturer's recommendation. Finally, cells were analyzed with BD FACSCalibur Flow Cytometer system (USA) and raw data processed by Flow Jo software version 7.6.1.

\section{Vital staining of rBMMSCs via Cell Tracker}

We used a Cell Tracker dye to follow recruitment and homing of rBMMSCs into the pulmonary parenchyma in sensitized rats. After trypsinization, cells were labeled with $2 \mu \mathrm{M}$ Cell Tracker $^{\text {Tm }} \mathrm{CM}-\mathrm{Dil}$ at $37^{\circ} \mathrm{C}$ for $20 \mathrm{~min}$ (Catalog No. C-7000; Molecular Probes, Invitrogen, USA). A total number of $2 \times 10^{6} \mathrm{CM}$-Dil pre-labeled cells in $50 \mu \mathrm{l}$ of PBS was administrated gently to each animal's femoral vein.

\section{Conditioned media (CM) harvesting}

Possible paracrine effects of rBMMSCs in the alleviation of ovalbumin-induced asthma intensity were investigated by rBMMSCs-derived CM. By $70-80 \%$ confluency, the exhausted DMEM/LG was discarded and cells were washed three times with PBS. Subsequently, DMEM/LG-free FBS was added to flasks (Mao et al. 2013a). The supernatant was collected after $72 \mathrm{~h}$, centrifuged at $400 \times g$ for $5 \mathrm{~min}$, filtered by $0.20-\mu \mathrm{m}$-pore syringe filter. An approximately 50 -fold concentrated solution was prepared by using centrifuge filter tubes with molecular weight cut-offs at $4 \mathrm{kDa}$ (Catalog No. 003099.125, Eppendorf, Germany). The protein content of concentrated CM was measured by using bicinchoninic acid assay (BCA assay, iNtRon, Korea). Our preliminary analysis showed that total protein content of concentrated CM reached to $500 \mu \mathrm{g} / \mathrm{ml}$. An equal volume of $\mathrm{CM}$, containing similar protein concentration was used in this experiment. We injected $50 \mu \mathrm{l}$ of concentrated CM per case intravenously (Abreu et al. 2013a).

\section{Animal sensitization and animal groups}

In this study, 40 healthy mature male Wistar rats with body weight at range of 200-250 $g$ were used. The animals were accommodated in standard cages at $20 \pm 2{ }^{\circ} \mathrm{C}$ under 12:12 light/dark cycle with free access to food and water. Then, four healthy rats were randomly allocated for extraction of rBMMSCs prior to sensitization process. The remaining rats were classified into two main groups; healthy (C) and sensitized (S) rats which further were divided into 3 subgroups, each included six animals. The control (C) and sensitized (S) rats were treated as follows:

1. Rats only received $50 \mu \mathrm{l}$ PBS (C and S)

2. Rats received $50 \mu \mathrm{l} \mathrm{CM}$ (CSV and SSV)

3. Rats received $50 \mu \mathrm{l}$ PBS containing $2 \times 10^{6}$ rBMMSCs (CCV and SCV)

In the sensitized groups, rats were exposed with ovalbumin over a course of $32 \pm 1$ days according to previously published methods (Schuster et al. 2000). Each animal was intraperitoneally (i.p.) co-injected with the combination of $1 \mathrm{mg}$ of ovalbumin (Sigma-Aldrich, USA) and $200 \mathrm{mg}$ aluminum hydroxide, as adjuvant, pre-dissolved in $1 \mathrm{ml}$ saline on first and $8^{\text {th }}$ days. By $14^{\text {th }}$ day, the sensitized rats were accommodated to aerosolized environment of $4 \%$ ovalbumin generating by a nebulizer (CX3, Omron Co., Netherland), for $18 \pm 1$ consecutive days. Our protocol last for an approximate period of 5 min daily. The experiment was tailored in a special locked box with dimensions $30 \times 20 \times 20 \mathrm{~cm}^{3}$. In control rats without any sensitization, saline solution was used instead of ovalbumin using the same protocol (Neamati et al. 2013). One-day post-sensitization, the rats were enrolled to the experimental procedure of cell adminstration or CM treatment through the left femoral vein (Ahmadi et al. 2016). Calling attention, some authorities declared that the respiratory responses related to ovalbumin-induced sensitization continued over a course of two weeks (Khazdair et al. 2013; Gholamnezhad et al. 2014).

\section{Tracking of migrated cell by immunofluorescence assay}

Snap-frozen and sectioned at $5 \mu \mathrm{m}$ thickness were prepared using a Cryostat apparatus to ascertain the presence of injected cells in respiratory tissues (Rahbarghazi et al. 2014). The prepared sections were thawed at room temperature, washed twice with PBS (5 min each) and stained with 4', 6-diamidino-2-phenylindole (DAPI, $1 \mu \mathrm{g} / \mathrm{ml}$, Catalog\# D9542, Sigma-Aldrich, USA) for background counterstaining.

\section{Total RNA extraction and real-time PCR}

Two weeks after injection of cell suspension or CM, rats were anesthetized with the combination of ketamine and xylazine solution $(75 \mathrm{mg} / \mathrm{kg}$ and $3 \mathrm{mg} / \mathrm{kg}$ i.p.). Left lung was instantly excised, washed with saline solution and snap-frozen in liquid nitrogen. Then, total RNA from lung homogenate was extracted using Total RNA extraction mini kit (YTA, Taiwan) according to manufacturer's instruction (Biyashev et al. 2012; Lässer et al. 2012). The purity of isolated RNAs were confirmed by a NanoDrop 1000 Spectrophotometer (Thermo Scientific, Wilmington DE 19810 USA). The ex- 
pression of $I L-4, I L-13, I L-10$, miRNA133 and miRNA155 genes were quantitatively assessed by real-time PCR. Primer sequences for each mRNAs were chosen using Gene-Runner Software, version 3.05 (Table 1). Reverse transcription was performed by cDNA Synthesis Kit (YTA, Taiwan) to determine mRNA expression levels. In addition, the expression profile of miRNAs was performed on total RNA extracts by miR-amp kit (Parsgenome Co, Iran). Each cDNA was used as a template for separate assay for miRNAs and mRNAs quantitative real-time PCR by using SYBR Green master mix (YTA, Taiwan). Real-time PCR reactions were carried out on a Rotor-Gene 6000 instrument (Corbett Life Science, Australia). Housekeeping GAPDH (glyceraldehyde3-phosphate dehydrogenase) gene was used to normalize the amount of PCR products for mRNA samples and miRNA191 for miRNA133 and miRNA155. We used $2^{-\Delta \Delta C T}$ formula to ascertain relative-quantitative expression levels of individual miRNAs and mRNAs. The results were expressed as fold change versus the relevant controls.

\section{Pathological evaluation}

The right lung of each animal was removed and fixed in buffer formalin 10\% (37\%, Merck, Germany). After one week, tissue specimens were processed through Passage method by increasing ethanol concentrations (up to 100\%), cleared by xylol, and embedded in paraffin. Serial 4-micron thick sections were cut by a microtome. Finally, all sections were carefully mounted on glass slides stained by hematoxylineosin (H\&E) solution and assessed by a light microscope. The pathological changes were observed in the lungs of all experimental groups including hyperemia, leukocyte infiltration, epithelialization, emphysema, and atelectasis varied greatly from none to scattered changes. We defined grades according to the following manner: 0 , absence of pathologic changes; 1 , patchy changes; 2 , local changes; 3 , scattered changes.

\section{Statistical analysis}

All quantitative data were analyzed by one-way analysis of variance (ANOVA) with the Tukey-Kramer post-hoc test and expressed as mean \pm SEM. Histopathological scores between the groups were analyzed using Kruskal-Wallis test with the post-hoc Mann-Whitney test. Significance was accepted at $p<0.05$.

\section{Results}

\section{Stemness characterization}

We confirmed that expanded MSCs evidently expressed stemness-related markers CD133 and CD44 while the
A

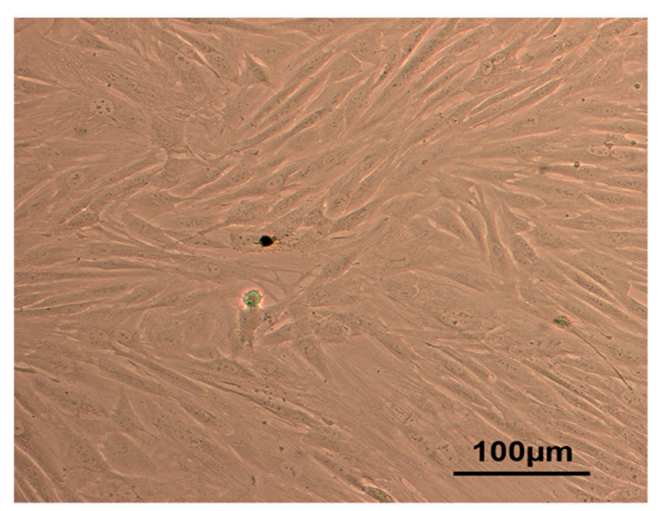

B

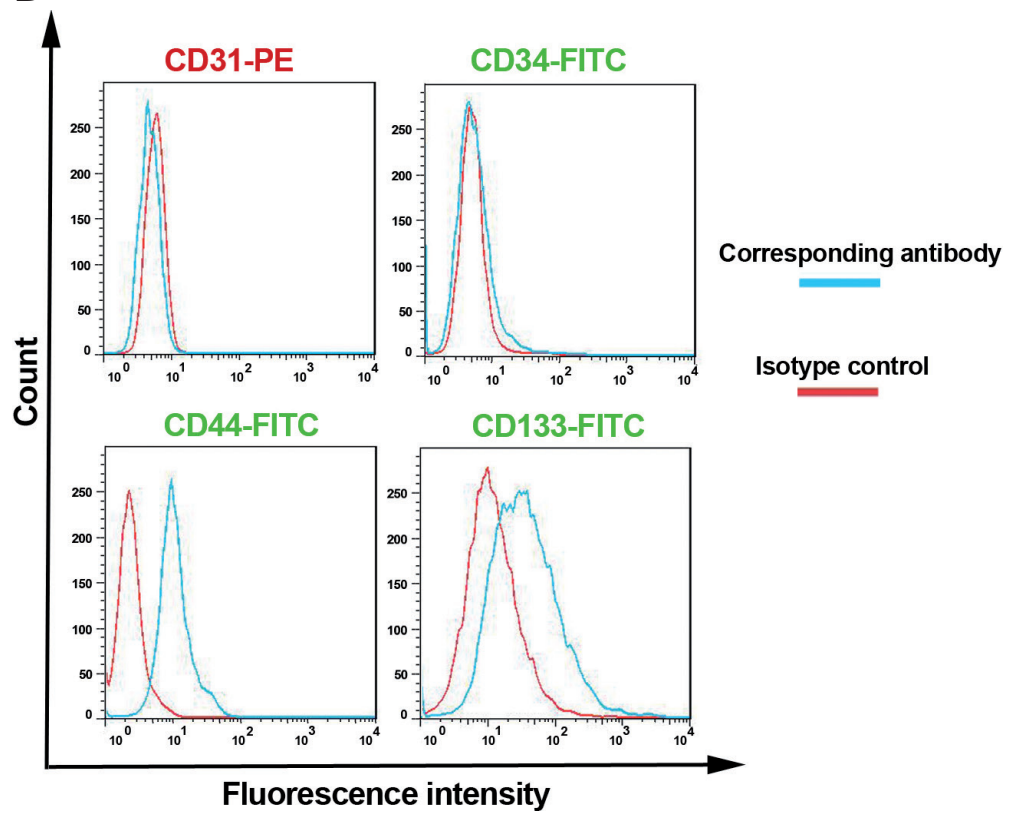

Figure 1. A. Phase contrast micrographs of the confluent monolayer of rBMMSCs at third passage. B. Cultured rBMMSCs phenotypic characterization. The expression of both positive and negative cell surface markers of cultured cells was evaluated by flow cytometry analysis. Histograms demonstrate cells positively stained with CD133 and CD44. (See online version for color figure.) 
negative markers, CD31 and CD34 were not identified (Figure 1).

MSCs efficiently modulated the IL-4, IL-13 and IL-10 $m R N A$ levels in asthmatic lungs

Quantitative transcript analysis of the interleukins in all sensitized groups showed a marked expression in the levels of IL-4 and IL-13 with decrease of IL-10 in comparison with $\mathrm{C}$ group $(p<0.001$ to $p<0.01)$. Compared with other sensitized groups, the expression of interleukins in asthmatic rats received MSCs showed drastic difference. In detail, the expression levels of IL-4 and IL-13 diminished significantly $(p<0.05)$, whereas IL-10 increased simultaneously $(p<$ $0.01)$. Based to our results, no significant modulatory effects of CM injection were achieved in terms of IL-4, IL-13 and IL-10 levels in asthmatic rats (Figure 2).

MSCs normalized the expression of miRNA133 and miRNA155 in asthmatic rats

We detected that miRNA133 gene expression was decreased significantly in all sensitized groups in comparison with the control rats $(p<0.001)$. There was a significant increase in SCV group as compared to other sensitized groups $(p<0.01)$. However, there were no significant differences between $S$ and SSV groups. miRNA133 gene expression in CCV and CSV groups were more similar to control group (Figure $3 \mathrm{~A}$ ). On the other hand, miRNA155 gene expression was increased significantly in all sensitized groups as compared with $C$ group $(p<0.001$ to $p<0.01)$. There was a significant decrease in SCV group compared to other sensitized groups $(p<0.05)$. Similar to miRNA133, there were no significant differences in the expression of miRNA155 between S and SSV groups. In addition, the pattern of miRNA155 expression in CCV and CSV groups were more similar to group C (Figure 3B).

\section{Pre-labeled cells appropriately recruited into pulmonary parenchyma}

The presence of pre-labeled rBMMSCs was determined either in non-sensitized and peculiarly sensitized animals received cells via systemic injection. Our data were also shown that injected MSCs could recruit into lungs of nonsensitized control rats, regarding the homing proficiency of MSCs (Figure 4).

\section{Pathological results}

Pathological changes observed in the pulmonary environments of all sensitized groups were significantly higher than $\mathrm{C}$ group $(p<0.001$ to $p<0.05)$. There was a significant decrease in the all-pathological changes of SCV group, unless
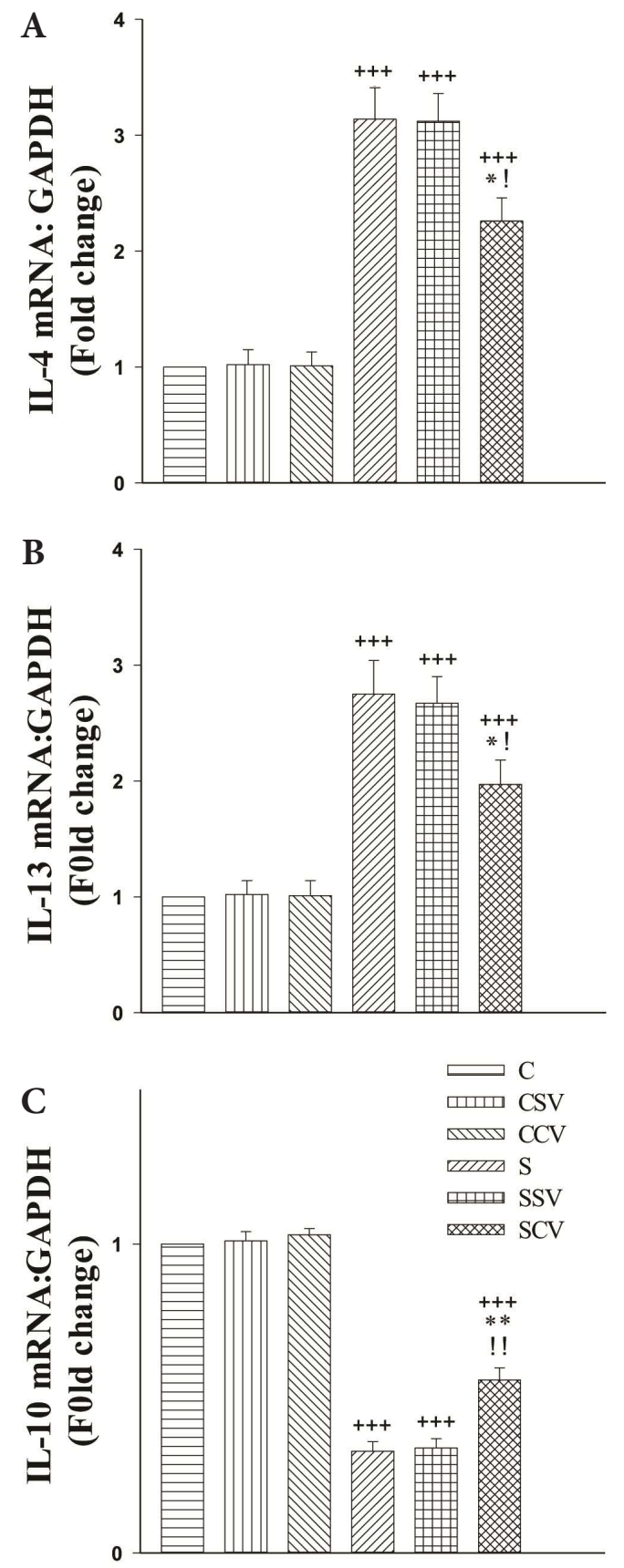

Figure 2. Expression levels of IL-4 (A), IL-13 (B) and IL-10 (C) mRNA in the lung tissue of control group received PBS (C), control group received CM (CSV), control group received rBMMSCs (CCV), sensitized animals received PBS (S), sensitized animals received CM (SSV), sensitized animals received rBMMSCs (SCV) (for each group, $n=6$ ). Bars represent the mean \pm SEM. Statistical differences between control and different groups: ${ }^{++} p<0.01$ and ${ }^{+++} p<0.001$. Statistical differences between SSV and SCV $v s$. $S$ group: ${ }^{\star} p<0.05$ and ${ }^{* *} p<0.01$. Statistical differences between SSV and SCV groups: $! p<0.05$ and $! " p<0.01$. CM, conditioned media; PBS, phosphate-buffered solution; rBMMSCs, bone marrow-derived mesenchymal stem cells. 

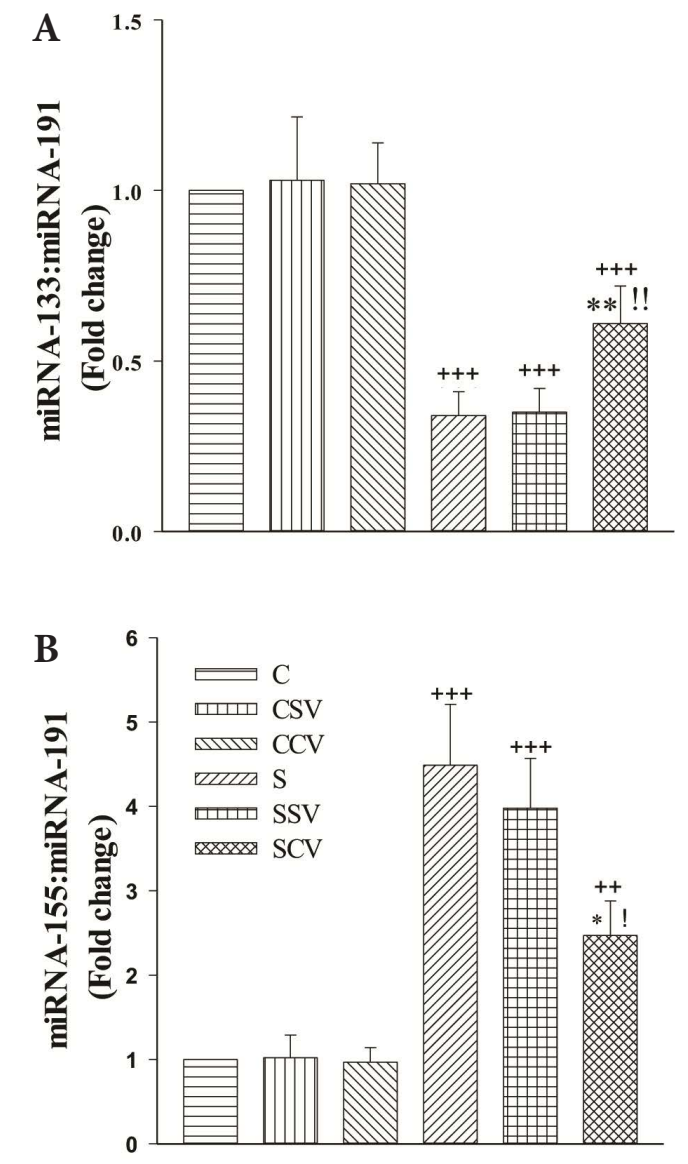

Figure 3. Real-time quantitative RT-PCR analysis of miR-133 (A) and miR-155 (B) expression level in lung of control group received PBS (C), control group received CM (CSV), control group received rBMMSCs (CCV), sensitized animals received PBS(S), sensitized animals received $\mathrm{CM}$ (SSV), sensitized animals received rBMMSCs (SCV) (for each group, $n=6$ ). Bars represent the mean \pm SEM. Statistical differences between control and different groups: ${ }^{++} p<$ $0.01,{ }^{+++} p<0.001$. Statistical differences between SSV and SCV $v s$. S group: ${ }^{\star} p<0.05,{ }^{* *} p<0.01$. Statistical differences between SSV and SCV groups: ' $p<0.05, ! " p<0.01$. For abbreviations, see Fig. 2.

atelectasis, in comparison with S and SSV groups $(p<0.01$ to $p<0.05)$. Calling attention, the pathological changes in SSV group were more similar to S group (Figure 5, Table 2).

\section{Discussion}

In spite of apparent advances in human medicine, asthma still is not curable. Pathological changes in the lung structure of asthmatic subjects are mainly induced by chronic inflammatory responses. Accordingly, the efficient strategy must be directed to control the intensity and period of aberrant inflammation (Kavanagh and Mahon 2011; Vosooghi et al.
2013; Keyhanmanesh et al. 2014). Concurrently, owning immune-regulatory features, it makes MSCs and CM eligible to be used extensively for ameliorating lung inflammatory disorders such as asthma and COPD (Goodwin et al. 2011; Ionescu et al. 2012; Abreu et al. 2014; Feizpour et al. 2014; Chen et al. 2015; Ahmadi et al. 2017). Because of numerous similarities to human, rats were therefore selected in the current experiment. Previously, Abreu showed that therapeutic effects of BMMCs reduced in ovalbumin-sensitized mice as compared with healthy animals, MSCs were obtained from non-sensitized rats (Pauluhn and Mohr 2005; Abreu et al. 2014). It has been conceived that BMMSCs could significantly suppress Th2 cytokines levels, promoted Treg cell responses, and prevent allergic airway inflammation in ovalbumin-induced asthma. Nevertheless, no enough data exist on the modulatory effects of MSCs on the expression levels of miRNAs studied in rat model of asthma (Bonfield et al. 2010; Kavanagh and Mahon 2011; Zeng et al. 2015). Our aim, in selecting a suitable cell fraction as well as $\mathrm{CM}$ was to explore the underlying mechanisms by which MSCs exert immune-modulatory properties for attenuating chronic asthmatic changes.

In the current study, the paracrine effects of intravenously injected rBMMSCs and relevant CM phase were individually investigated in terms of the expression of IL-4, IL-13, IL-10, miRNA133, miRNA155 along with pathological changes in the lungs of sensitized rats. Our pathological findings revealed that lesions observed in the lung tissue of the ovalbumin-sensitized groups were significantly higher than the control rats, indicating the rat model of asthma was constructed successfully (Ebrahimi et al. 2016; Mohammadian et al. 2016b). Similar to previous findings, a significant reduction in the expression of IL-10 and miRNA133, coincided with a remarkable increase in the expression of IL-4, IL-13 and miRNA155 were seen in all sensitized groups as compared with healthy rats (Rankin et al. 1996; Chiba et al. 2009; Dong et al. 2014; Malmhäll et al. 2014; Fallahi et al. 2016).

Based on data, following systemic injection of rBMMSCs, the observed pathological changes were significantly reduced unless atelectasis, showing that rBMMSCs significantly diminished inflammation rate which was supported by some previous experimental findings (Firinci et al. 2011; Mohammadian et al. 2016b). In addition, the systemic injection of rBMMSCs blunted the levels of IL-4, IL-13, IL-10, miRNA133, and miRNA155 in pulmonary specimens of sensitized rats to near normal levels. In contrary, MSCs-CM did not initiate any obvious effects on the levels of measured miRNAs, interleukins and pathological changes in lung tissues of sensitized rats. The application of both MSCs and CM has inert effects on normal healthy tissue, and we did not find any obvious change in the levels of measured miRNAs and interleukins of saline-challenged rats. Unlike to our results, some experi- 
ments showed that the intravenous injection of MSC-CM decreased inflammation and improved local tissue damage and therapeutic effects of direct administration of CM were most similar to BMMSCs (Timmers et al. 2011; Ionescu et al.
2012; Gazdhar et al. 2014; Zhu et al. 2014). Failure of systemic administration of CM on the factors measured in this study could be possibly related to animal species studied, sensitization technique, the source, volume, route and time of cell
A

Non-sensitized rats
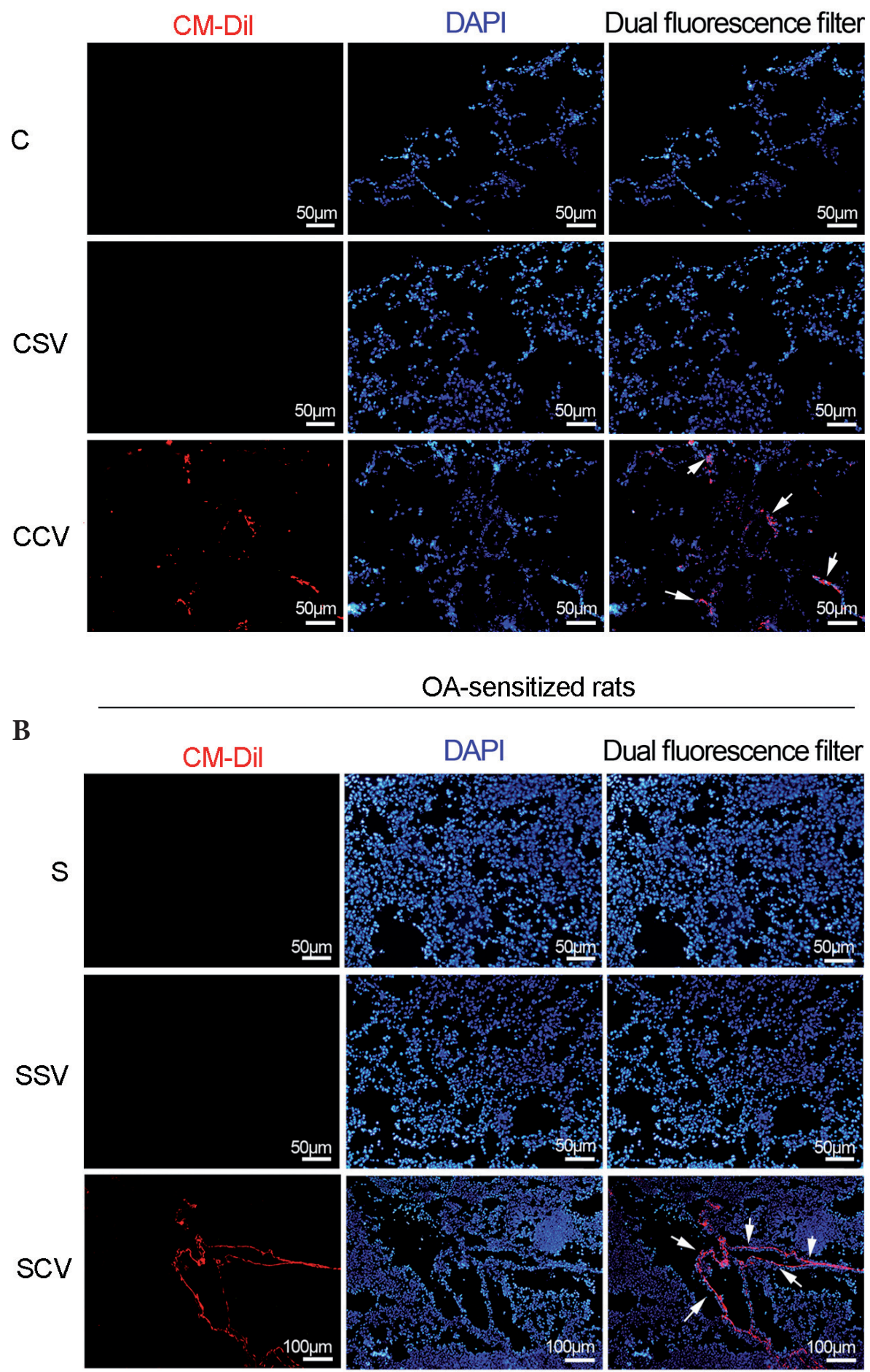

Figure 4. Representative images of fluorescent-tagged rBMMSCs in lungs parenchyma of non-sensitized (A) and sensitized rats (B). The existence of rBMMSCs was evident in all rats given cells by systemic approach. Interestingly, the number of recruited cells was more profound in the sensitized rats as compared with non-sensitized control. For background staining, DAPI solution was used. Control group received PBS (C), control group received CM (CSV), control group received $\mathrm{rB}$ MMSCs (CCV), sensitized animals received $\mathrm{PBS}(\mathrm{S})$, sensitized animals received CM (SSV),sensitized animals received rBMMSCs (SCV). (See online version for color figure.) 
and CM administration (Bonios et al. 2011; Ma et al. 2014). Moreover, MSCs release their active factors "spontaneously" or after induction by the local situations, it seems that one of the most possible reasons for effects of rBMMSCs compared with $\mathrm{CM}$ is the variation in quality and quantity of secreted agents. On the other hand, the secretome could be easily dispersed in the peripheral tissues and not reach efficiently and completely into the injured sites. Another possible for this statement is due to the fact that the factors within the $\mathrm{CM}$ are consumed by the surrounding injured tissue, because the CM contains only a limited amount of factors whereas the presence of the stem cells provides an available source for the chronic secretion of soluble agents (Sutsko et al. 2012; Kyurkchiev et al. 2014). Injection with high volume, recurrent doses, and intra-tracheal injection may be effective.

To date, several possible mechanisms regarding asthma pathophysiology have been reported. Given that numerous
miRNAs expressed differentially in asthmatic subjects as compared with healthy subjects, miRNAs were described to play a key role in the induction of asthma (Tang et al. 2016). A plethora of experiments showed, for example, the up-regulation of miRNA155 and down-regulation of miRNA133 in the mouse model of OVA-induced asthma and miRNAs dynamic targeting could add invaluable data in allergic asthma therapy regarding on asthma Th2 and Treg cytokines levels (Chiba et al. 2009; Wang et al. 2011; Kuo et al. 2013; Malmhäll et al. 2014; Kai et al. 2015). Of 296 miRNAs studied via miRNA PCR in samples collected from lung tissues in mice model, Tang et al. (2016) introduced miR-21/Acvr2a axis play actively key role on the induction of asthmatic inflammation. For example, they also showed that miRNA21a and Th2 cytokines levels remarkably was affected immediately after administration of MSCs. The dynamic changes of both miRNAs expression along with
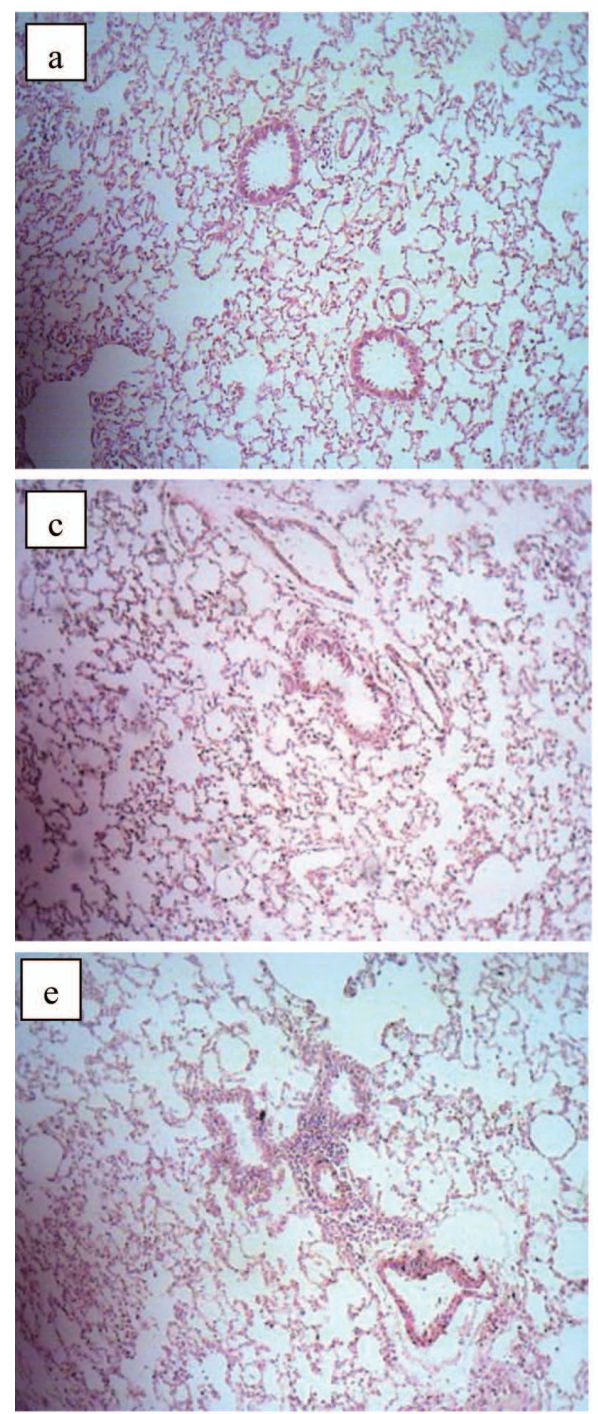
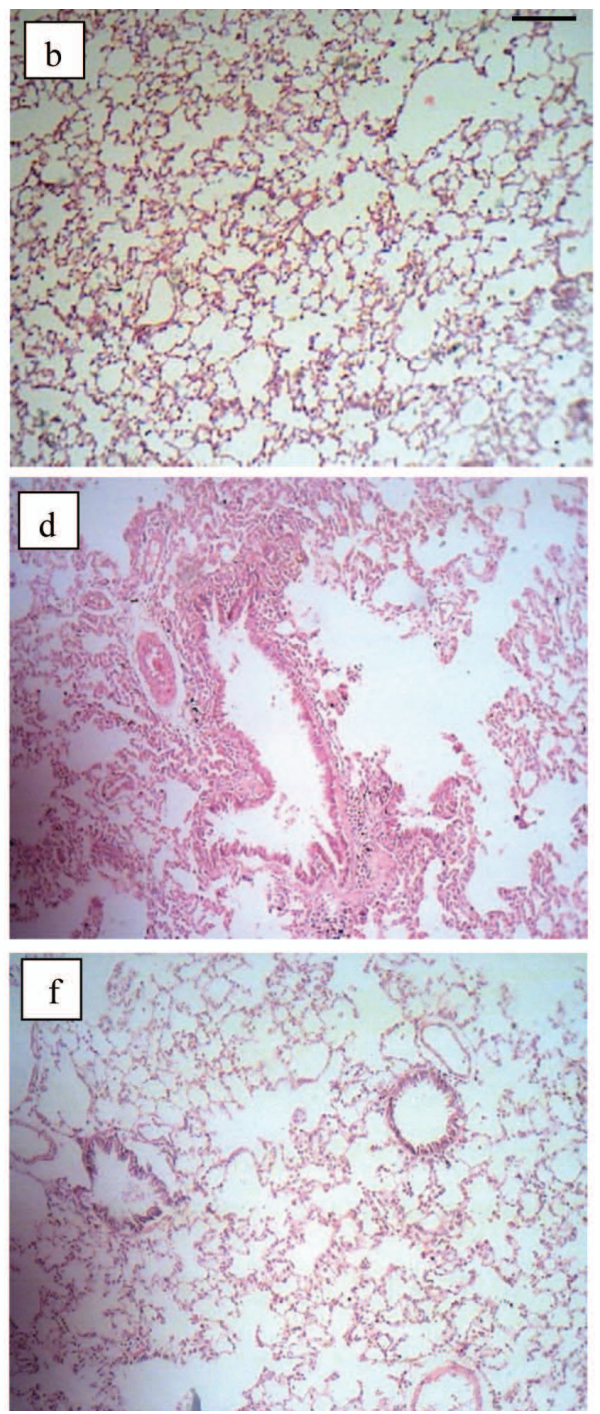

Figure 5. Photographs of a lung specimen in different groups (magnification for each group; $8 \times 10$ ). Normal lung tissue in control group received $\mathrm{PBS}(\mathrm{C}, \mathbf{a})$, control group received CM (CSV, b) and control group received rBMMSCs $(\mathrm{CCV}, \mathbf{c})$. Cell infiltration and emphysema in sensitized group received PBS $(\mathrm{S}, \mathbf{d})$, cell infiltration in sensitized group received CM (SSV, e) and sensitized group received rBMMSCs (SCV, f). (See online version for color figure.) 
pathological changes and measured cytokines pre- and post-MSC transplantation, mainly in SCV rats, could denote that the therapeutic effects of MSCs occurred likely by the modulation of our targeted miRNAs.

Based on the crucial effect of both miR155 and miR133a in ongoing pathological changes of asthma, it was elucidated that over-expression of miR155 seen during T lymphocyte differentiation, recruitment and the production of inflammatory cytokines (Kai et al. 2015). It was well-established that MSC-derived micro-particles, notably exosomes, contained miRNA array that could act as RNA interference (RNAi) in the recipient cells and tissues (Pegtel et al. 2010). By producing and the release of numerous anti-immunogenic factors, such as TGF- $\beta$, PGE2 and NO via MSCs exosome, it was shown the dynamic changes of miRNAs could be regulated by affecting the function of $\mathrm{T}$ and $\mathrm{B}$ lymphocytes as well as natural killer cells in target tissues containing progenitor cells (Di Trapani et al. 2016). In the current study, an appropriate number of pre-labeled MSCs were proved in pulmonary tissues of non-asthmatic and peculiarly asthmatic rats. In contrast to our result, some authorities revealed MSCs homing, exclusively in injured lung tissue (Abreu et al. 2013b; Ghorbani et al. 2014; Mohammadian et al. 2016a). It is hypothesized that many factors could alter the homing capacity of MSCs. According to animal strain and species, stem cells type, injection routes and volumes, recovery time after cell therapy, severity and type of tissue injury and volume and type of cell tracker used in different experiments, a controversial data has obtained (Abe et al. 2004; Herzog et al. 2006; Lee et al. 2009; Abreu et al. 2013b; Trzil et al. 2014). There are also certain limitations regarding current experiment. For example, we did not investigate the miRNA target genes and related signaling pathways. Also, long-term monitoring would be helpful to mimic the real changes during asthmatic changes. In conclusion, the outcomes of current investigation showed that intravenous administration of rBMMSCs, but not CM, could be effective in alleviation of asthma pathophysiology, presumably by the modulation of essential miRNAs in ovalbumin-sensitized rats.

Acknowledgement. This project was supported by student research committee of Tabriz University of Medical Sciences.

Conflict of Interest. None declared.

\section{References}

Abe S, Boye C, Liu X, Wen FQ, Kobayashi T, Fang Q, Wang X, Hashimoto M, Sharp JG, Rennard SI (2004): Cells derived from the circulation contribute to the repair of lung injury. Am. J. Respir. Crit. Care Med. 170, 1158-1163 https://doi.org/10.1164/rccm.200307-908OC
Abreu SC, Antunes MA, de Castro JC, de Oliveira MV, Bandeira E, Ornellas DS, Diaz BL, Morales MM, Xisto DG, Rocco PR (2013a): Bone marrow-derived mononuclear cells vs. mesenchymal stromal cells in experimental allergic asthma. Respir. Physiol. Neurobiol. 187, 190-198 https://doi.org/10.1016/j.resp.2013.03.014

Abreu SC, Antunes MA, Maron-Gutierrez T, Cruz FF, Ornellas DS, Silva AL, Diaz BL, Ab'Saber AM, Capelozzi VL, Xisto DG (2013b): Bone marrow mononuclear cell therapy in experimental allergic asthma: intratracheal versus intravenous administration. Respir. Physiol. Neurobiol. 185, 615-624 https://doi.org/10.1016/j.resp.2012.11.005

Abreu SC, Antunes MA, Mendonça L, Branco VC, de Melo EB, Olsen PC, Diaz BL, Weiss DJ, Paredes BD, Xisto DG (2014): Effects of bone marrow mononuclear cells from healthy or ovalbumin-induced lung inflammation donors on recipient allergic asthma mice. Stem Cell Res. Ther. 5, 108 https://doi.org/10.1186/scrt496

Ahmadi M, Rahbarghazi R, Soltani S, Aslani MR, Keyhanmanesh $\mathrm{R}$ (2016): Contributory anti-inflammatory effects of mesenchymal stem cells, not conditioned media, on ovalbumininduced asthmatic changes in male rats. Inflammation 39, 1960-1971 https://doi.org/10.1007/s10753-016-0431-2

Ahmadi M, Rahbarghazi R, Aslani MR, Shahbazfar AA, Kazemi M, Keyhanmanesh R (2017): Bone marrow mesenchymal stem cells and their conditioned media could potentially ameliorate ovalbuminnduced asthmatic changes. Biomed. Pharmacother. 85, 28-24 https://doi.org/10.1016/j.biopha.2016.11.127

Aslani MR, Keyhanmanesh R, Khamaneh AM, Abbasi MM, Fallahi M, Alipour MR (2016): Tracheal overexpression of IL-1 $\beta$, IRAK- 1 and TRAF- 6 mRNA in obese-asthmatic male Wistar rats. Iran J. Basic Med. Sci. 19, 350-357

Bharadwaj A, Agrawal DK (2004): Immunomodulation in asthma: a distant dream or a close reality? Int. Immunopharmacol. 4, 495-511

https://doi.org/10.1016/j.intimp.2004.02.001

Biyashev D, Veliceasa D, Topczewski J, Topczewska JM, Mizgirev I, Vinokour E, Reddi AL, Licht JD, Revskoy SY, Volpert OV (2012): miR-27b controls venous specification and tip cell fate. Blood 119, 2679-2687 https://doi.org/10.1182/blood-2011-07-370635

Bonfield TL, Koloze M, Lennon DP, Zuchowski B, Yang SE, Caplan AI (2010): Human mesenchymal stem cells suppress chronic airway inflammation in the murine ovalbumin asthma model. Am. J. Physiol. Lung Cell Mol. Physiol. 299, 760-770 https://doi.org/10.1152/ajplung.00182.2009

Bonios M, Terrovitis J, Chang CY, Engles JM, Higuchi T, Lautamäki R, Yu J, Fox J, Pomper M, Wahl RL (2011): Myocardial substrate and route of administration determine acute cardiac retention and lung bio-distribution of cardiosphere-derived cells. J. Nucl. Cardiol. 18, 443-450 https://doi.org/10.1007/s12350-011-9369-9

Chen J, Li C, Chen L (2015): The role of microvesicles derived from mesenchymal stem cells in lung diseases. Biomed. Res. Int. 2015, 985814 https://doi.org/10.1155/2015/985814 
Chiba Y, Tanabe M, Goto K, Sakai H (2009): Down-regulation of miR-133a contributes to up-regulation of Rhoa in bronchial smooth muscle cells. Am. J. Respir. Crit. Care Med. 180, 713-719 https://doi.org/10.1164/rccm.200903-0325OC

D‘Cruz DP, Barnes NC, Lockwood CM (1999): Difficult asthma or Churg-Strauss syndrome? BMJ 318, 475-476 https://doi.org/10.1136/bmj.318.7182.475

Di Trapani M, Bassi G, Midolo M, Gatti A, Kamga PT, Cassaro A, Carusone R, Adamo A, Krampera M (2016): Differential and transferable modulatory effects of mesenchymal stromal cellderived extracellular vesicles on T, B and NK cell functions. Sci Rep. 6, 24120 https://doi.org/10.1038/srep24120

Dong F, Wang C, Duan J, Zhang W, Xiang D, Li M (2014): Puerarin attenuates ovalbumin-induced lung inflammation and hemostatic unbalance in rat asthma model. Evid Based Complement Alternat Med. 2014, 726740 https://doi.org/10.1155/2014/726740

Douglas G, Higgins B, Barnes N, Boyter A, Burge S, Cates C, Connett G, Couriel J, Cullinan P, Edwards S (2008): British guideline on the management of asthma: a national clinical guideline. Thorax. 63, iv1-iv121 https://doi.org/10.1136/thx.2008.097741

Ebrahimi H, Fallahi M, Khamaneh AM, Saadatlou E, Ali M, Saadat S, Keyhanmanesh R (2016): Effect of $\alpha$-hederin on IL-2 and IL-17 mRNA and miRNA133a levels in lungs of ovalbuminsensitized male rats. Drug Dev. Res. 77, 87-93 https://doi.org/10.1002/ddr.21292

Fallahi M, Keyhanmanesh R, Khamaneh AM, Saadatlou MAE, Saadat S, Ebrahimi H (2016): Effect of Alpha-Hederin, the active constituent of Nigella sativa, on miRNA126, IL-13 mRNA levels and inflammation of lungs in ovalbumin-sensitized male rats. Avicenna J. Phytomed. 6, 77-85

Feizpour A, Boskabady MH, Ghorbani A (2014): Adipose-derived stromal cell therapy affects lung inflammation and tracheal responsiveness in guinea pig model of COPD. PLoS One. 9, e108974 https://doi.org/10.1371/journal.pone.0108974

Firinci F, Karaman M, Baran Y, Bagriyanik A, Ayyildiz ZA, Kiray M, Kozanoglu I, Yilmaz O, Uzuner N, Karaman O (2011): Mesenchymal stem cells ameliorate the histopathological changes in a murine model of chronic asthma. Int. Immunopharmacol. 11, 1120-1126 https://doi.org/10.1016/j.intimp.2011.03.009

Gallina C, Turinetto V, Giachino C (2015): A new paradigm in cardiac regeneration: the mesenchymal stem cell secretome. Stem Cells Int. 2015, 765846 https://doi.org/10.1155/2015/765846

Garbacki N, Di Valentin E, Geurts P, Irrthum A, Crahay C, Arnould T, Deroanne C, Piette J, Cataldo D, Colige A (2011): MicroRNAs profiling in murine models of acute and chronic asthma: a relationship with mRNAs targets. PLoS One 6, e16509 https://doi.org/10.1371/journal.pone.0016509

Gazdhar A, Grad I, Tamò L, Gugger M, Feki A, Geiser T (2014): The secretome of induced pluripotent stem cells reduces lung fibrosis in part by hepatocyte growth factor. Stem Cell Res Ther. 5, 123 https://doi.org/10.1186/scrt513

Gholamnezhad Z, Boskabady MH, Khazdair MR, Hosseini M, Abbasnejad M (2014): Effect of fluticasone and salmeterolon tracheal responsiveness to ovalbumin and lung inflammation, administrated during and after sensitization. Sci. World J. 2014, 865292

https://doi.org/10.1155/2014/865292

Ghorbani A, Feizpour A, Hashemzahi M, Gholami L, Hosseini M, Soukhtanloo M, Bagheri FV, Khodaei E, Roshan NM, Boskabady MH (2014): The effect of adipose derived stromal cells on oxidative stress level, lung emphysema and white blood cells of guinea pigs model of thechronic obstructive pulmonary disease. Daru 22, 22-26 https://doi.org/10.1186/2008-2231-22-26

Goodwin M, Sueblinvong V, Eisenhauer P, Ziats NP, LeClair L, Poynter ME, Steele C, Rincon M, Weiss DJ (2011): Bone marrow-derived mesenchymal stromal cells inhibit Th2-mediated allergic airways inflammation in mice. Stem Cells 29, $1137-1148$

https://doi.org/10.1002/stem.656

Guilbert TW, Morgan WJ, Zeiger RS, Mauger DT, Boehmer SJ, Szefler SJ, Bacharier LB, Lemanske Jr RF, Strunk RC, Allen DB (2006): Long-term inhaled corticosteroids in preschool children at high risk for asthma. N. Engl. J. Med. 354, 1985-1997 https://doi.org/10.1056/NEJMoa051378

Herzog EL, Van Arnam J, Hu B, Krause DS (2006): Threshold of lung injury required for the appearance of marrow-derived lung epithelia. Stem Cells 24, 1986-1992 https://doi.org/10.1634/stemcells.2005-0579

Horie M, Choi H, Lee RH, Reger RL, Ylostalo J, Muneta T, Sekiya I, Prockop DJ (2012): Intra-articular injection of human mesenchymal stem cells (MSCs) promote rat meniscal regeneration by being activated to express Indian hedgehog that enhances expression of type II collagen. Osteoarthritis Cartilage 20, 1197-1207 https://doi.org/10.1016/j.joca.2012.06.002

Huang TJ, Adcock IM, Chung KF (2001): A novel transcription factor inhibitor, SP100030, inhibits cytokine gene expression, but not airway eosinophilia or hyperresponsiveness in sensitized and allergen-exposed rat. Br. J. Pharmacol. 134, 1029-1036 https://doi.org/10.1038/sj.bjp.0704344

Ionescu L, Byrne RN, van Haaften T, Vadivel A, Alphonse RS, ReyParra GJ, Weissmann G, Hall A, Eaton F, Thébaud B (2012): Stem cell conditioned medium improves acute lung injury in mice: in vivo evidence for stem cell paracrine action. Am. J. Physiol. Lung Cell Mol. Physiol. 303, L967-L977 https://doi.org/10.1152/ajplung.00144.2011

Kai W, Xu Q, Wu ZQ (2015): MicroRNAs and Asthma Regulation. Iran J. Allergy Asthma Immunol. 14, 120-125

Kavanagh H, Mahon B (2011): Allogeneic mesenchymal stem cells prevent allergic airway inflammation by inducing murine regulatory T cells. Allergy 66, 523-531 https://doi.org/10.1111/j.1398-9995.2010.02509.x

Keyhanmanesh R, Pejman L, Omrani H, Mirzamohammadi Z, Shahbazfar AA (2014): The effect of single dose of thymoquinone, the main constituents of Nigella sativa, in guinea pig model of asthma. Bioimpacts 4, 75-81 
Khazdair MR, Boskabady MH, Tabatabaee A, Hosseini M, Abbasnejad M (2013): Effect of inhaled fluticasone and salmeterol on tracheal responsiveness and lung inflammation: Influence of administration time and allergen-free period. Indian J. Med. Sci. 67, 78-88 https://doi.org/10.4103/0019-5359.121121

Kishore A, Borucka J, Petrkova J, Petrek M (2014): Novel insights into miRNA in lung and heart inflammatory diseases. Mediators Inflamm. 2014, 259131 https://doi.org/10.1155/2014/259131

Kuo Y-C, Li Y, Zhou J, Shih Y, Miller M, Broide D, Lee O, Chien S (2013): Human mesenchymal stem cells suppress the stretchinduced inflammatory miR-155 and cytokines in bronchial epithelial cells. PLoS One 8, e71342 https://doi.org/10.1371/journal.pone.0071342

Kyurkchiev D, Bochev I, Ivanova-Todorova E, Mourdjeva M, Oreshkova T, Belemezova K, Kyurkchiev S (2014): Secretion of immunoregulatory cytokines by mesenchymal stem cells. World J. Stem Cells 6, 552-570 https://doi.org/10.4252/wjsc.v6.i5.552

Lässer C, Eldh M, Lötvall J (2012): Isolation and characterization of RNA-containing exosomes. J. Vis. Exp. e3037 https://doi.org/10.3791/3037

Lee RH, Pulin AA, Seo MJ, Kota DJ, Ylostalo J, Larson BL, Semprun-Prieto L, Delafontaine P, Prockop DJ (2009): Intravenous hMSCs improve myocardial infarction in mice because cells embolized in lung are activated to secrete the anti-inflammatory protein TSG-6. Cell Stem Cell 5, 54-63 https://doi.org/10.1016/j.stem.2009.05.003

Ma S, Xie N, Li W, Yuan B, Shi Y, Wang Y (2014): Immunobiology of mesenchymal stem cells. Cell Death Differ. 21, 216-225 https://doi.org/10.1038/cdd.2013.158

Malmhäll C, Alawieh S, Lu Y, Sjöstrand M, Bossios A, Eldh M, Rådinger M (2014): MicroRNA-155 is essential for T H 2-mediated allergen-induced eosinophilic inflammation in the lung. J. Allergy Clin. Immunol. 133, 1429-1438 https://doi.org/10.1016/j.jaci.2013.11.008

Mao Q, Lin C-X, Liang X-L, Gao J-S, Xu B (2013): Mesenchymal stem cells overexpressing integrin-linked kinase attenuate cardiac fibroblast proliferation and collagen synthesis through paracrine actions. Mol. Med. Rep.7, 1617-1623 https://doi.org/10.3892/mmr.2013.1348

Martinez FD (2007): Genes, environments, development and asthma: a reappraisal. Eur. Respir. J. 29, 179-184 https://doi.org/10.1183/09031936.00087906

Mi S, Zhang J, Zhang W, Huang RS (2013): Circulating microRNAs as biomarkers for inflammatory diseases. Microrna 2, 64-72 https://doi.org/10.2174/2211536611302010007

Mohammadian M, Boskabady MH, Kashani IR, Jahromi GP, Omidi A, Nejad AK, Khamse S, Sadeghipour HR (2016a): Effect of bone marrow derived mesenchymal stem cells on lung pathology and inflammation in ovalbumin-induced asthma in mouse. Iran J. Basic Med. Sci. 19, 55-63

Mohammadian M, Sadeghipour HR, Kashani IR, Jahromi GP, Omidi A, Nejad AK, Golchoobian R, Boskabady MH (2016b): Evaluation of simvastatin and bone marrow-derived mesenchymal stem cell combination therapy on airway remodeling in a mouse asthma model. Lung 194, 777-785 https://doi.org/10.1007/s00408-016-9884-1

Murray CJ, Lopez AD (1997): Alternative projections of mortality and disability by cause 1990-2020: Global burden of disease study. Lancet 349, 1498-1504

https://doi.org/10.1016/S0140-6736(96)07492-2

Neamati A, Boskabady MH, Mahdavi-Shahri N, Mahmoudabady M (2013): The preventive effect of Brassica napus L. oil on pathophysiological changes of respiratory system in experimental asthmatic rat. Avicenna J. Phytomed. 3, 56-63

Pauluhn J, Mohr U (2005): Experimental approaches to evaluate respiratory allergy in animal models. Exp. Toxicol. Pathol. 56, 203-234

https://doi.org/10.1016/j.etp.2004.10.002

Pegtel DM, Cosmopoulos K, Thorley-Lawson DA, van Eijndhoven MA, Hopmans ES, Lindenberg JL, de Gruijl TD, Würdinger T, Middeldorp JM (2010): Functional delivery of viral miRNAs via exosomes. Proc. Natl. Acad. Sci. USA 107, 6328-6333 https://doi.org/10.1073/pnas.0914843107

Rahbarghazi R, Nassiri SM, Khazraiinia P, Kajbafzadeh A-M, Ahmadi SH, Mohammadi E, Molazem M, Zamani-Ahmadmahmudi M (2012): Juxtacrine and paracrine interactions of rat marrow-derived mesenchymal stem cells, muscle-derived satellite cells, and neonatal cardiomyocytes with endothelial cells in angiogenesis dynamics. Stem Cells Dev. 22, 855-865 https://doi.org/10.1089/scd.2012.0377

Rahbarghazi R, Nassiri SM, Ahmadi SH, Mohammadi E, Rabbani S, Araghi A, Hosseinkhani H (2014): Dynamic induction of pro-angiogenic milieu after transplantation of marrow-derived mesenchymal stem cells in experimental myocardial infarction. Int. J. Cardiol. 173, 453-466 https://doi.org/10.1016/j.ijcard.2014.03.008

Rankin JA, Picarella DE, Geba GP, Temann U-A, Prasad B, DiCosmo B, Tarallo A, Stripp B, Whitsett J, Flavell RA (1996): Phenotypic and physiologic characterization of transgenic mice expressing interleukin 4 in the lung: lymphocytic and eosinophilic inflammation without airway hyperreactivity. Proc. Natl. Acad. Sci. USA 93, 7821-7825

https://doi.org/10.1073/pnas.93.15.7821

Rebane A, Akdis CA (2014): MicroRNAs in allergy and asthma. Curr. Allergy Asthma Rep. 14, 1-9

https://doi.org/10.1007/s11882-014-0424-x

Schuster M, Tschernig T, Krug N, Pabst R, (2000): Lymphocytes migrate from the blood into the bronchoalveolar lavage and lung parenchyma in the asthma model of the brown Norway rat. Am. J. Respir. Crit. Care Med. 161, 558-566 https://doi.org/10.1164/ajrccm.161.2.9812021

Simpson LJ, Patel S, Bhakta NR, Choy DF, Brightbill HD, Ren X, Wang Y, Pua HH, Baumjohann D, Montoya MM (2014): A microRNA upregulated in asthma airway $\mathrm{T}$ cells promotes $\mathrm{TH} 2$ cytokine production. Nat. Immunol. 15, 1162-1170 https://doi.org/10.1038/ni.3026

Sun YQ, Deng MX, He J, Zeng QX, Wen W, Wong DS, Tse HF, Xu G, Lian Q, Shi J (2012): Human pluripotent stem cell-derived mesenchymal stem cells prevent allergic airway inflammation in mice. Stem Cells 30, 2692-2699

https://doi.org/10.1002/stem.1241

Sutsko RP, Young KC, Ribeiro A, Torres E, Rodriguez M, Hehre D, Devia C, McNiece I, Suguihara C (2012): Long-term reparative 
effects of mesenchymal stem cell therapy following neonatal hyperoxia-induced lung injury. Pediatr. Res. 73, 46-53 https://doi.org/10.1038/pr.2012.152

Sze SK, de Kleijn DP, Lai RC, Tan EKW, Zhao H, Yeo KS, Low TY, Lian Q, Lee CN, Mitchell W (2007): Elucidating the secretion proteome of human embryonic stem cell-derived mesenchymal stem cells. Mol. Cell. Proteomics 6, 1680-1689 https://doi.org/10.1074/mcp.M600393-MCP200

Tang G-N, Li C-L, Yao Y, Xu Z-B, Deng M-X, Wang S-Y, Sun Y-Q, Shi J-B, Fu Q-L (2016): MicroRNAs involved in asthma after mesenchymal stem cells treatment. Stem Cells Dev. 25, 883-896 https://doi.org/10.1089/scd.2015.0339

Timmers L, Lim SK, Hoefer IE, Arslan F, Lai RC, van Oorschot AA, Goumans MJ, Strijder C, Sze SK, Choo A (2011): Human mesenchymal stem cell-conditioned medium improvescardiac function following myocardial infarction. Stem Cell Res. 6, 206-214 https://doi.org/10.1016/j.scr.2011.01.001

Todorova L (2007): Effects of asthma combination therapy on extracellular matrix remodeling in human lung fibroblasts: Lung biology

Trzil JE, Masseau I, Webb TL, Chang CH, Dodam JR, Cohn LA, Liu H, Quimby JM, Dow SW, Reinero CR (2014): Long-term evaluation of mesenchymal stem cell therapy in a feline model of chronic allergic asthma. Clin. Exp. Allergy 44, 1546-1557

https://doi.org/10.1111/cea.12411

Vosooghi S, Mahmoudabady M, Neamati A, Aghababa H (2013): Preventive effects of hydroalcoholic extract of saffron on hematological parameters of experimental asthmatic rats. Avicenna J. Phytomed. 3, 279-287

Wang J, Li K, Hellermann G, Lockey RF, Mohapatra S, Mohapatra S (2011): Regulating the regulators: microRNA and asthma. World Allergy Organ J. 4, 94-103 https://doi.org/10.1186/1939-4551-4-6-94

Zeng SL, Wang LH, Li P, Wang W, Yang J: Mesenchymal stem cells abrogate experimental asthma by altering dendritic cell function. Mol. Med. Rep. 12, 2511-2520 https://doi.org/10.3892/mmr.2015.3706

Zhu Yg, Feng Xm, Abbott J, Fang Xh, Hao Q, Monsel A, Qu Jm, Matthay MA, Lee JW (2014): Human mesenchymal stem cell microvesicles for treatment of Escherichia coli endotoxin-induced acute lung injury in mice. Stem Cells 32, 116-125 https://doi.org/10.1002/stem.1504

Received: June 8, 2017

Final version accepted: October 25, 2017 